\title{
Conduta em Paciente Testemunha de Jeová sob o Enfoque da Bioética
}

\author{
Medical Conduct in a Jehovah's Witness Patient from the Bioethics Point of View
}

\section{Max Grinberg e Graziela Zlotnik Chehaibar}

Instituto do Coração - InCor, São Paulo, SP - Brasil

\section{Ao leitor}

Este caso suscita três possíveis condutas. Acesse o endereço http://www.arquivosonline.com.br/enquete/artigo2689.asp e marque a sua opção.

Mulher de 68 anos, batizada há 2 anos como Testemunha de Jeová (TJ), foi internada pelo SUS com insuficiência cardíaca para uma cirurgia de troca de prótese biológica mitral com disfunção importante.

A paciente apresentou um termo assinado e registrado em cartório, assinado por duas testemunhas, no qual dizia que ela não aceitava receber nenhum tipo de derivado de sangue e isentava de responsabilidade toda a equipe médica em casos de intercorrências com indicação de transfusão de sangue.

A equipe profissional conversou com a paciente e deixou claro que uma terceira operação de grande porte estava associada à alta probabilidade de uma transfusão de sangue.

A paciente pediu para ser tratada com técnicas alternativas que não a transfusão de sangue, não autorizando o procedimento em nenhuma situação.

Qual a sua conduta?

\section{Opção 1: Recusar-se a cuidar da paciente}

Recusar o tratamento cirúrgico é maneira de o médico respeitar a autonomia da paciente, ou seja, sua capacidade de governar a si mesma, livre de interferência ou pressão externa.

Opção 2: Providenciar o tratamento cirúrgico e realizar transfusão de sangue caso haja evidente risco à vida da paciente

Transfundir o paciente quando houver risco iminente de vida é direcionar intervenção em beneficio do seu paciente, acreditando que a vida tem um valor superior em relação às crenças.

\section{Opção 3: Providenciar o tratamento cirúrgico e não} transfundir sangue em nenhuma hipótese

O médico acredita que o principio da autonomia precisa ser legitimado e respeitado. Sendo assim, o paciente tem direito de recusar um tratamento médico mesmo em circunstâncias de iminente risco de vida . O médico respeita as convicções da paciente sem impor as suas próprias, fazendo do respeito pelas escolhas um ato beneficente.

\section{Palavras-chave}

Comportamento, Testemunha de Jeová, bioética. 